\title{
The Relationship Between Environmental Degradation, Poverty and Human Quality in Indonesia
}

\author{
Shanty Oktavilia ${ }^{1}$, Dita Wahyu Puspita ${ }^{2}$, Firmansyah $^{3}, F X$ Sugiyanto $^{3}$ \\ ${ }^{1}$ Faculty of Economics, Universitas Negeri Semarang and Doctoral Program in Economics, Universitas Diponegoro, \\ Semarang, Indonesia \\ ${ }^{2}$ Faculty of Economics, Universitas Negeri Semarang, Semarang, Indonesia \\ ${ }^{3}$ Faculty of Economics and Business, Universitas Diponegoro, Semarang, Indonesia
}

\begin{abstract}
Economic growth, environmental quality, and human quality affect each other. The economic growth which is driven primarily by industrialization and trade openness, degrades the environment. Meanwhile, the growth and environmental quality can affect human quality. This research analyzes those relationship by develop two panel econometrics models for 31 provinces in Indonesia during 2010-2015. The first model examines how the environmental quality, economic growth, poverty rate, population density, and global trade affect human development index as representation of human quality. The second model analyzes the effect of economic growth, human quality, population density, poverty, and global trade on environmental quality. This study finds that the economic growth, environmental quality and globalization affect human quality in Indonesia positively, while the poverty and population density affect negatively. The human quality have positive effect on environmental quality in Indonesia, while the economic growth, global trade, poverty and population density variables have the negative effect.
\end{abstract}

Keywords: environmental degradation; environmental quality; human quality; economic liberalization; poverty.

\section{Introduction}

The concept of human development and sustainable economy has evolved into a debate in economic studies. Solow's idea of the importance of human development in a country's economic development in the neoclassical growth model suggests that human development is the result of economic growth and is also as an input to grow the economy itself [1]. The subsequent development of thoughts are related to human capital in determining the rate of economic growth which are related to health and nutrition, education, and which later maturate as modern endogenous growth theory [2].

Economic growth increases negative externalities. Economic development is not only attended by an increase in real income per capita. Other indicators of development success include decreasing literacy rate, increasing life expectancy, improving nation's welfare, quality of life and environmental quality. Sustainable economic development is expected to meet current needs without sacrificing future needs. This is accomplished by increasing the supply of physical capital, human capital, technological and environmental improvements. The results of research in some poor and developing countries showed the environmental quality decreased along with the increase of economic growth.

Another problem of economic and environmental development is poverty. Some studies suggest that the poor do not have enough resources to adopt sustainable activities. In addition, institutional and market failures also affect environmental degradation and poverty. Dasgupta, found a positive relationship between rural poverty, fertility and degradation of environmental resources [3]. The conclusion of the study is that besides poverty, institutional failure is also the cause of environmental degradation. Contrary to Dasgupta's study, another research suggests that the poor do not have sufficient resources to damage the environment. This is because the poor in the short term still rely on natural products, so they will take good care of the environment.

* Corresponding author: email:oktavilia@gmail.com 
Indonesia as a developing country also has economic and environmental problems. Provincial-based data, showing some regions experiencing high economic growth, but the level of poverty is also high. Economic indicators simultaneously illustrate the increase in economic growth in some areas followed by improving the quality of human resources. However, a good indicator is followed by a decrease in environmental quality.

\section{Methodology}

This study uses panel data that is a combination of time series and cross section, because of the limitations of data in long series [4]. The data used are secondary data of 33 provinces in Indonesia, and range from 2011-2015. Panel data regression model can be obtained an efficient estimation result because of the increasing number of observations and degree of freedom. This research chose the best model with fixed effect model (FEM) and random effect model (REM), which is determined by Hausman Test [5].

This study uses two objectives, namely the relationship between economic growth, environmental quality, human-resource quality and poverty. The first model investigates the effect of economic growth (GDRB), human quality (HDI), population density (PDENS), poverty (POV) and global trade (TRADE) on environmental quality (EQI). Empirical models are written by equations:

$$
\begin{gathered}
\mathrm{LEQI}_{\mathrm{it}}=\beta_{0}+\beta_{1} \mathrm{LGDRB}_{\mathrm{it}}+\beta_{2} \mathrm{LHDI}_{\mathrm{it}}+\beta_{3} \mathrm{LPDENS}_{\mathrm{it}}+ \\
\beta_{4} \mathrm{LPOV}_{\mathrm{it}}+\beta_{5} \mathrm{LTRADE}_{\mathrm{it}}+\mathrm{u}_{\mathrm{it}} \ldots \ldots \ldots \ldots \ldots . . . .1(1)
\end{gathered}
$$

The second model examines the effects of economic growth (GDRB), Environmental Quality (EQI), population density (PDENS), poverty (POV) and global trade (TRADE) on human quality (HDI). The Second models are written by equations:

$$
\begin{aligned}
& \mathrm{LHDI}_{\mathrm{it}}=\alpha_{0}+\alpha_{1} \mathrm{LGDRB}_{\mathrm{it}}+\alpha_{2} \mathrm{LEQI}_{\mathrm{it}}+\alpha_{3} \mathrm{LPDENS}_{\mathrm{it}}+ \\
& \alpha_{4} \mathrm{LPOV}_{\text {it }}+\alpha_{5} \mathrm{LTRADE}_{\mathrm{it}}+\mathrm{e}_{\mathrm{it}}
\end{aligned}
$$

In both models, (L) shows the natural logarithm, (u) and (e) are the error terms, (i) shows the observations based on provinces and ( $\mathrm{t}$ ) shows the observations based on the time series.

\section{Discussion}

The panel data model required selection of the best model with Hausman-test. The score of Chi - Square statistic Hausman-test is 12.040382 . It confirmations that REM model may be rejected that FEM model is used. The first model shows that regional income, poverty and population density variables are negatively related to environmental quality. Meanwhile, human development and global trade variables individually have a positive and significant.
Table 1. Estimation result of panel data model: dependent variable of environmental quality

\begin{tabular}{|l|l|l|l|l|}
\hline & \multicolumn{2}{|l|}{ FEM } & \multicolumn{2}{l|}{ REM } \\
\hline Variable & Coefficient & t-Statistic & Coefficient & t-Statistic \\
\hline LOG(GDRB) & -0.079255 & $-9.107768 *$ & -0.346898 & $-1.895836 * *$ \\
\hline LOG(HDI) & 0.159849 & $3.251969 *$ & 0.003265 & 1.124446 \\
\hline LOG(POV) & -0.048926 & $-7.755779 *$ & -0.064298 & -0.259744 \\
\hline LOG(PDENS) & -0.081789 & $-49.18567 *$ & -0.002416 & $-5.075649 *$ \\
\hline LOG(TRADE) & -0.007461 & $-2.923694 *$ & -6.372917 & -0.754008 \\
\hline \multicolumn{1}{|c|}{ C } & 4.460909 & $24.39963 *$ & -0.346898 & $5.116012 *$ \\
\hline
\end{tabular}

Notes: *) significant at $5 \% ; * *)$ significant at $10 \%$

Estimated results with FEM show that a 1 percent increase in economic growth will degrade environmental quality by 0.079 percent. These results indicate that the characteristics of development in Indonesia are at the stage of the formulation of the Kuznets Curve Environment that growth has a negative impact to the environment. Improved economic activity on a larger scale will lead to an increase in environmental damage. This is due to excessive resource exploration and unsustainable industrialization [6].

The results of regression with the first model show the following: Increased poverty by 1 percent, able to reduce the environmental quality index by 0.04 percent. The increase in human quality as indicated by the 1 percent increase in human development index increased the environmental quality index by 0.15 percent. The population density and global trade variables show a negative relationship. Increased population density by 1 percent decreased environmental quality by 0.08 percent. The 1 percent increase in global trade decreased the environmental quality by 0.007 percent.

The average intercepts value of the first empirical model is 4.46 (significant at alpha 1 percent). This means that the FEM model is able to explain the differences in the behavior of the five independent variables on environmental quality. The result of estimation yields the coefficient of determination $\left(\mathrm{R}^{2}\right)$ value of 0.788 . This shows that 78.8 percent of the total variation of environmental quality variables can be explained by the five independent variables and 21.2 percent are explained by variations of other variables.

Table 2. Estimation result of panel data model: dependent variable of human quality (HDI)

\begin{tabular}{|l|l|l|l|l|}
\hline \multicolumn{2}{|l|}{ FEM } & \multicolumn{3}{l|}{ REM } \\
\hline Variable & Coefficient & t-Statistic & Coefficient & t-Statistic \\
\hline LOG(GDRB) & 0.032414 & $10.99894 *$ & 0.021305 & $4.22533 *$ \\
\hline LOG(EQI) & 0.033036 & $2.784698^{*}$ & 0.003095 & 0.342975 \\
\hline LOG(POV) & -0.041078 & $-19.59238^{*}$ & -0.003538 & $-2.434862 *$ \\
\hline LOG(PDENS) & -0.025877 & $-27.10187 *$ & -0.005572 & $1.909136 *$ \\
\hline LOG(TRADE) & 0.000579 & 0.603281 & 0.000178 & 0.519924 \\
\hline C & 3.821121 & $58.22720 *$ & 3.967847 & $54.28080 *$ \\
\hline
\end{tabular}

Notes: *) significant at $5 \% ; * *)$ significant at $10 \%$

The second model aims to analyze the effects of economic growth, environmental quality, poverty, 
population density, and global trade on human quality in Indonesia. The results of both FEM and REM estimates indicate that independent variables are compatible with the hypothesis in affecting human quality. However, the Hausman-test (Chi-square statistic 32.510352) shows that the REM model is rejected to use over the FEM model. Then, the second model will be analyzed and interpreted using FEM model.

The second model estimation result with FEM yields the mean intercepts value for the overall model of 3,821 (significant at alpha 1 percent). This means that the model is able to explain the difference of behavior of the five independent variables to the human quality variable in Indonesia. The influence of independent variables to the dependent variable is explained as follows: Poverty variable and population density have negative effect on dependent variable. Economic growth, environmental quality and global trade has a positive effect on human quality. Overall of the independent variables significantly affect human quality variable except global trade variable.

Estimation results show an increase in economic growth by 1 percent, affecting human quality improvement of 0.03 percent. The effect of 1 percent increase in environmental quality leads to an increase in human quality by 0.03 percent. The increase in poverty by 1 percent affects the decline in human quality by 0.04 percent. Increase in population density by 1 percent affects the decline in human quality by 0.025 percent. The estimation results show the coefficient of determination $\left(\mathrm{R}^{2}\right)$ value of 0.66 . This means that 66 percent of the variation in the human quality variable can be explained by the independent variables, empirical and 34 percent is explained by variations in other variables.

This study explores the long-term relationship of economic growth, poverty, quality of human resources, and environmental quality in Indonesia. This study focuses on the variables of environmental quality and quality of human resources. The results indicate that expansion in economic activity, global trade, affect the quality of the environment and the quality of human resources. Poverty and population density also negatively affect the quality of the environment and human quality. Economic growth in Indonesia improves the quality of human resources, but increases environmental degradation. This is consistent across several studies relating to the relationship of economic growth and declining environmental quality in poor and developing countries [7].

\section{Conclusion}

The influence between environmental quality and human quality shows a one-way relationship.
Similarly, the quality of human resources also positively affects the quality to the environment in Indonesia. This study shows that the impact on human development is important to reduce environmental degradation and can play a positive role in achieving sustainable development. This study also corroborates some of the opinion of economists who claim that human-resource development is the key to sustainable economic development [8].

With regard to poverty issues, this study shows the negative effects of poverty on environmental quality and human quality. This research is in line with the opinion that poverty has the potential to encourage environmental damage. The poor have the potential to explore unplanned natural resources. It is also due to the inability of poor and developing country governments to adopt and implement green technologies. This is due to the concentrated government budget for poverty alleviation. The effect of population density became the recommendation of this study. Population distribution to low density areas is a solution to improve human quality and environmental quality.

\section{References}

1. R. M. Solow, Contribution to the Theory of Economic Growth (Quarterly Journal of Economics 70, 65-94, Stapleton 1956).

2. J. Klick, Autocrats and the Environment or It's Easy Being Green (Working Paper Series 02-16, George Mason University, 2002).

3. P. Dasgupta, C. Folke, K. G. Maler, The Environmental Resource Base and Human Welfare (Beijer Reprint Series, 35, Stockholm, 1994).

4. H. B. Baltagi, Econometric Analysis of Panel Data (Chicester, 2005).

5. N. D. Gujarati, D. C. Porter, Basic Econometrics $5^{\text {th }}$ ed, New York (McGraw-Hill, 2009).

6. B. R. Copeland, M. S. Taylor, Trade, Growth and the Environment (Journal of Economic Literature, 42 (1): 7-71, 2003).

7. T. Everett, L. Ishawaran, G. P. Ansaloni, A. Rubin, Economic Growth and the Environment, (Defra Evidence and Analysis Series 2, 2010).

8. V. Costantini, Sustainable development and human development: an integrated approach, Countries (Journal of Development Studies 36(6): 1-24, 2006).

9. Statistics Indonesia, Indicator of Sustainable Development (Badan Pusat Statistik- BPS, 20112016).

10. Statistics Indonesia, Environment Statistics of Indonesia (Badan Pusat Statistik - BPS, 20112016). 